\title{
Membrane diffusing capacity and pulmonary capillary volume in rheumatoid disease
}

\author{
ELIZABETH A HILLS AND MARION GEARY
}

From Stoke Mandeville Hospital, Aylesbury, Buckinghamshire

ABSTRACT In some patients with rheumatoid disease gas transfer across the lungs is abnormal. We measured the membrane component of gas transfer (Dm) and pulmonary capillary volume (Vc) in 48 patients with rheumatoid arthritis and in 48 normal volunteers matched for age, sex, and smoking habits. Volunteers had normal chest radiographs and normal forced expiratory volume in one second and vital capacity. There were no significant differences between the rheumatoid and control groups for Dm. Mean Vc in rheumatoid male smokers $(64.0 \mathrm{ml}$, SD 16.5) was significantly lower than in control male smokers $(76.3 \mathrm{ml}$, SD $18.0 \mathrm{p}<0.05)$. In rheumatoid female smokers mean Vc (43.4 ml, SD 13.3) was significantly lower than in rheumatoid female non-smokers $(58.4 \mathrm{ml}$, SD $15.4 \mathrm{p}<0.01)$. There was no significant difference between rheumatoid and control female non-smokers (mean Vc $58.4 \mathrm{ml}$ and $60.7 \mathrm{ml}$ respectively). Significant differences in Vc in terms of per cent predicted normal were found between patients receiving corticosteroids and those not receiving corticosteroids or penicillamine $(p<0.02)$ and between patients with nodules and those without $(\mathrm{p}<0 \cdot 05)$. Patients with persistently low transfer factor for five years had a significantly lower Vc $(p<0.02)$. There was no consistent correlation between Dm and Vc and dynamic compliance or static recoil pressure. It appears that the abnormality of transfer factor in rheumatoid disease previously demonstrated is caused by reduction of Vc. It seems that involvement of pulmonary blood vessels occurs in patients with nodules and is suppressed by treatment with corticosteroids.

In their report of lung involvement in rheumatoid disease Ellman and Ball ${ }^{1}$ described the pathology in two patients. In one there was interstitial pneumonitis, fibrosis between alveoli, and some endothelial proliferation with fibrinoid degeneration of blood vessels. In the other case there was interstitial pneumonitis and cuboidal epithelium was described in the alveoli. There was also intra-alveolar fibrosis but the blood vessels were normal. Subsequent reports $^{2-5}$ sometimes described prominent alveolar or bronchiolar inflammatory changes and in some cases there was marked arterial involvement. Some descriptions were of fibrosis with or without arterial changes. Subsequent studies of respiratory function in rheumatoid disease ${ }^{6-8}$ showed that transfer factor ( $\left.T_{L}\right)$ was low in many patients. We have extended these observations by determining the membrane factor (Dm) and pulmonary capillary volume $(\mathrm{Vc})$, the components of transfer factor, in patients with rheumatoid disease.

Address for reprint requests: Dr EA Hills, Stoke Mandeville Hospital, Mandeville Road, Aylesbury, Buckinghamshire HP21 8AL

\section{Methods}

Forty-eight patients with classical or definite rheumatoid arthritis were attending hospital annually for respiratory function tests. They were not studied at the time of any acute respiratory tract infection or within seven days after receiving a general anaesthetic. They were matched for age, sex, and smoking habits with 48 normal volunteers. The normal subjects had no symptoms of respiratory disease, normal chest radiographs, and normal forced expiratory volume in one second and vital capacity. Transfer factor for carbon monoxide was measured by the single breath method using a Morgan Resparameter or Transfertest as described by Cotes. ${ }^{9}$ Patients breathed pure oxygen for five minutes before each of the first two estimations when the inspired mixture was $\mathrm{CO}$ and helium in oxygen (high $\mathrm{Po}_{2}$ ). After 20 minutes two estimations were made in air $\left(\right.$ low $\left.\mathrm{Po}_{2}\right)$ of $\mathrm{TL}$ with an inspired mixture of $0.28 \%$ carbon monoxide and $14 \%$ helium in air. For each test, patients expired to functional residual volume before inspiring to total 
lung capacity. The breath-holding time was 10 seconds, the washout volume was 0.7 litres, and sample volume 0.7 litres. Back tension of carbon monoxide (BT CO) was measured by re-breathing into a three litre bag of oxygen for four minutes. Carbon dioxide was absorbed by soda lime. rebreathing $\mathrm{CO}$ concentration $\times$ expired $\mathrm{O}_{2}$ concentration

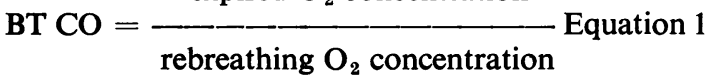

Back tension of carbon monoxide was measured before the first and again before the second or after the fourth $T_{L}$ test. The appropriate value for each test was judged by extrapolation or interpolation and BT CO was subtracted from measured inspired and expired $\mathrm{CO}$ concentration. $\theta$ was calculated for each test using the formula

$$
\frac{1}{\theta}=\frac{0.0057 \mathrm{Po}_{2}+0.33}{\mathrm{Hb} \%} \text { Equation } 2
$$

$(\theta=\mathrm{ml}$ carbon monoxide uptake $/ \mathrm{ml}$ blood $/ \mathrm{mm} \mathrm{Hg})$

$\mathrm{Po}_{2}=$ expired concentration $\mathrm{O}_{2}$

$\mathrm{Hb} \%=$ measured $\mathrm{Hb}$ g per $\mathrm{dl}$

$$
14 \cdot 8 \mathrm{~g} \text { per } \mathrm{dl}
$$

which assumes that $\lambda$, the ratio of oxygen uptake by red cell membrane to uptake by red cell interior, is $\infty$. Since

$$
\frac{1}{\mathrm{~T} L}=\frac{1}{\mathrm{Dm}}+\frac{1}{\theta \mathrm{Vc}} \quad \text { Equation } 3
$$

from the experiments at high and normal $\mathrm{Po}_{2}$ two values of $\mathrm{TL}_{\mathrm{L}}$ and $\theta$ are obtained, and $\mathrm{Dm}$ and $\mathrm{Vc}$ can then be calculated. ${ }^{9-11} \mathrm{We}$ did this by plotting $1 / \mathrm{TL}_{\mathrm{L}}$ against $1 / \theta$ and measuring slope $(1 / \mathrm{Vc})$ and intercept (1/Dm). Dynamic compliance (Cdyn) was measured as described in a previous paper. ${ }^{12}$

\section{Results}

Mean age, height, and $T_{L}$ on air are shown with mean Dm and Vc in table 1. Rheumatoid and control groups did not differ significantly in terms of age, height, or TL on air, nor was Dm found to be different between groups. Pulmonary capillary volume was significantly lower in male rheumatoic응 smokers compared with controls $(p=<0.05) \frac{\bar{s}}{\bar{s}}$ There was no significant difference between rheuma $\widetilde{\nabla}$ toid and control females, but $\mathrm{Vc}$ was significantly lower in rheumatoid women who smoked coms pared with those who did not $(\mathrm{p}=<0.01)$. How $\overrightarrow{0}$ ever, there was no difference between control female smokers and non-smokers.

To compare various groups of rheumatoid patients Dm and Vc were expressed as per cent predicted (PN). ${ }^{13}{ }^{14}$ Mean values for various groups are givener in table 2. There were no significant differences forDm. Pulmonary capillary volume was significantlyog lower in patients not receiving corticosteroids $(\mathrm{p}<0.02)$ and in patients with nodules $(\mathrm{p}=<0.025) \mathrm{g}$ but there was no significant correlation $(\mathrm{r}=-0 \cdot 12)-$ with Rose Waaler titre. There was no significant $Z$ relationship between $\mathrm{Dm}$ and $\mathrm{Vc}$ and the number of joints involved, nor between Dm and duration of arthritis $(r=-0 \cdot 24)$, but there was a significanto relationship ( $\mathrm{p}=<0.01$ ) between $\mathrm{Vc}$ and duration of arthritis $(r=0.34)$.

In those patients who had shown persistently low. $\mathrm{TL}, \mathrm{Vc}$ was significantly lower $(\mathrm{p}=<0.02)$ than in those whose $T_{L}$ had been normal at most visits. In the patients who had two out of three positive findings of cough, breathlessness, and abnormal\% chest radiographs at each visit compared with those who did not, there was no significant difference in $\overrightarrow{\vec{B}}$ Dm or Vc. In 15 patients Dm was less than $70 \%$ predicted but only five of these patients had per-J sistently low TL. In 26 patients Vc was less than $70 \%$. predicted; in $10 \mathrm{TL}$ had been persistently low. In seven patients both $\mathrm{Dm}$ and Vc were lower than $70 \%$ 응 predicted. Four of these had been known to have low $\mathrm{TL}$, but only two had persistent symptoms ando abnormal chest radiographs.

There was no consistent pattern of relationship between $\mathrm{Dm}$ and Vc and Cdyn. The correlation coefficients for Cdyn with Dm were -0.39 for 17 maleo rheumatoid smokers, $0 \cdot 44$ for 11 female rheumatoid smokers, and 0.57 for 11 female rheumatoid non-을. smokers. For Cdyn with Vc, $r$ for male smokers

\begin{tabular}{|c|c|c|c|c|c|c|c|c|c|c|c|}
\hline Group & Number & $\begin{array}{l}\text { Mean age } \\
\text { (yrs) }\end{array}$ & $S D$ & $\begin{array}{l}\text { Mean height } \\
\text { (metres) }\end{array}$ & $S D$ & $\begin{array}{l}\text { Mean } T L \\
\text { (air) }\end{array}$ & $S D$ & $D m$ & $S D$ & $\begin{array}{l}V c \\
(m l)\end{array}$ & $S D$ \\
\hline $\begin{array}{l}\text { Rheumatoid male smokers } \\
\text { Control male smokers } \\
\text { Rheumatoid female smokers } \\
\text { Control female smokers } \\
\text { Rheumatoid female non-smokers } \\
\text { Control female non-smokers }\end{array}$ & $\begin{array}{l}18 \\
18 \\
15 \\
15 \\
15 \\
15\end{array}$ & $\begin{array}{l}51 \cdot 5 \\
49 \cdot 4 \\
51 \cdot 0 \\
53 \cdot 3 \\
55 \cdot 1 \\
52 \cdot 6\end{array}$ & $\begin{array}{l}10 \cdot 55 \\
12 \cdot 99 \\
11 \cdot 32 \\
11 \cdot 05 \\
12 \cdot 57 \\
14 \cdot 55\end{array}$ & $\begin{array}{l}1 \cdot 73 \\
1 \cdot 77 \\
1 \cdot 63 \\
1 \cdot 65 \\
1 \cdot 60 \\
1 \cdot 65\end{array}$ & $\begin{array}{l}0.08 \\
0.07 \\
0.07 \\
0.07 \\
0.07 \\
0.07\end{array}$ & $\begin{array}{l}23 \cdot 82 \\
26 \cdot 98 \\
17 \cdot 88 \\
18 \cdot 64 \\
19 \cdot 47 \\
21 \cdot 15\end{array}$ & $\begin{array}{l}4 \cdot 58 \\
4 \cdot 86 \\
2 \cdot 42 \\
3 \cdot 80 \\
2 \cdot 95 \\
2 \cdot 75\end{array}$ & $\begin{array}{l}42 \cdot 34 \\
47 \cdot 32 \\
37 \cdot 69 \\
34 \cdot 07 \\
31 \cdot 32 \\
36 \cdot 01\end{array}$ & $\begin{array}{r}13 \cdot 95 \\
13 \cdot 27 \\
11 \cdot 70 \\
11 \cdot 04 \\
8 \cdot 82 \\
8 \cdot 90\end{array}$ & $\begin{array}{l}63 \cdot 99 \\
76 \cdot 27 \\
43 \cdot 40 \\
55 \cdot 32 \\
58 \cdot 35 \\
60 \cdot 56\end{array}$ & $\begin{array}{l}16 \cdot 49 \\
18 \cdot 01 \\
13 \cdot 32 \\
22 \cdot 06 \\
15 \cdot 35 \\
14 \cdot 24\end{array}$ \\
\hline
\end{tabular}
was 0.20 , for female smokers -0.71 , for female non-smokers $-0 \cdot 33$. In 28 patients $\mathrm{Dm}$ and $\mathrm{Vc}_{\mathrm{N}}$

Table 1 Mean $T_{L}$ air, Dm, and Vc in rheumatoid and control patients

$\mathrm{TL}$ and $\mathrm{Dm}$ in $\mathrm{ml} / \mathrm{min} / \mathrm{mmHg} \div 2.98=\mathrm{mmol} / \mathrm{kPa}$. 
Table $2 \mathrm{Dm}$ and $V c$ in terms of per cent predicted normal in various subgroups

\begin{tabular}{|c|c|c|c|c|c|c|}
\hline Group & Number & Smokers & $\begin{array}{l}\text { Mean } \\
\text { Dm }\end{array}$ & $S D$ & $\begin{array}{l}\text { Mean } \\
\text { Vc }\end{array}$ & $S D$ \\
\hline $\begin{array}{l}\text { Corticosteroid treatment } \\
\text { No corticosteroid or penicillamine } \\
\text { Corticosteroids and penicillamine }\end{array}$ & $\begin{array}{r}25 \\
16 \\
7\end{array}$ & $\begin{array}{r}17 \\
11 \\
5\end{array}$ & $\begin{array}{l}84 \cdot 1 \\
90 \cdot 7 \\
79 \cdot 4\end{array}$ & $\begin{array}{l}29 \cdot 99 \\
26 \cdot 56 \\
27 \cdot 71\end{array}$ & $\begin{array}{l}81 \cdot 8 \\
65 \cdot 1 \\
70 \cdot 9\end{array}$ & $\begin{array}{l}22 \cdot 37 \\
22 \cdot 73 \\
24 \cdot 25\end{array}$ \\
\hline $\begin{array}{l}\text { Patients with nodules } \\
\text { No nodules or sicca syndrome } \\
\text { Definite or possible sicca syndrome }\end{array}$ & $\begin{array}{r}19 \\
27 \\
7\end{array}$ & $\begin{array}{r}13 \\
21 \\
5\end{array}$ & $\begin{array}{l}87 \cdot 4 \\
83 \cdot 7 \\
84 \cdot 1\end{array}$ & $\begin{array}{l}34 \cdot 08 \\
23 \cdot 10 \\
24 \cdot 55\end{array}$ & $\begin{array}{l}62 \cdot 5 \\
80 \cdot 9 \\
66 \cdot 9\end{array}$ & $\begin{array}{l}22 \cdot 22 \\
25 \cdot 27 \\
17 \cdot 89\end{array}$ \\
\hline $\begin{array}{l}\mathrm{DSCAT}<1 / 256 \\
\mathrm{DSCAT}>1 / 256\end{array}$ & $\begin{array}{l}14 \\
34\end{array}$ & $\begin{array}{l}13 \\
23\end{array}$ & $\begin{array}{l}87 \cdot 4 \\
84 \cdot 9\end{array}$ & $\begin{array}{l}31 \cdot 10 \\
26 \cdot 66\end{array}$ & $\begin{array}{l}65 \cdot 7 \\
77 \cdot 1\end{array}$ & $\begin{array}{l}26 \cdot 26 \\
24 \cdot 19\end{array}$ \\
\hline $\begin{array}{l}\text { Duration of arthritis }<10 \mathrm{yr} \\
\text { Duration of arthritis }>10 \mathrm{yr} \\
<10 \text { joints involved } \\
>10 \text { joints involved }\end{array}$ & $\begin{array}{l}21 \\
27 \\
32 \\
16\end{array}$ & $\begin{array}{l}14 \\
19 \\
22 \\
11\end{array}$ & $\begin{array}{l}84 \cdot 6 \\
82 \cdot 6 \\
87 \cdot 1 \\
87 \cdot 1\end{array}$ & $\begin{array}{l}32 \cdot 43 \\
28 \cdot 69 \\
27 \cdot 58 \\
27 \cdot 36\end{array}$ & $\begin{array}{l}66 \cdot 5 \\
79 \cdot 4 \\
75 \cdot 9 \\
67 \cdot 8\end{array}$ & $\begin{array}{l}19 \cdot 57 \\
27 \cdot 72 \\
28 \cdot 26 \\
15 \cdot 56\end{array}$ \\
\hline $\begin{array}{l}\text { Airways obstruction } \\
\text { No airways obstruction. }\end{array}$ & $\begin{array}{l}15 \\
33\end{array}$ & $\begin{array}{l}12 \\
21\end{array}$ & $\begin{array}{l}81 \cdot 5 \\
87 \cdot 5\end{array}$ & $\begin{array}{l}19 \cdot 94 \\
30 \cdot 71\end{array}$ & $\begin{array}{l}79 \cdot 1 \\
73 \cdot 1\end{array}$ & $\begin{array}{l}29 \cdot 17 \\
21 \cdot 33\end{array}$ \\
\hline $\begin{array}{l}\text { Persistent symptoms and abnormal chest radiograph } \\
\text { No persistence of symptoms and abnormal chest radiograph }\end{array}$ & $\begin{array}{l}13 \\
35\end{array}$ & $\begin{array}{r}9 \\
24\end{array}$ & $\begin{array}{l}82 \cdot 3 \\
86 \cdot 9\end{array}$ & $\begin{array}{l}23 \cdot 16 \\
29 \cdot 48\end{array}$ & $\begin{array}{l}78 \cdot 7 \\
72 \cdot 0\end{array}$ & $\begin{array}{l}24 \cdot 72 \\
25 \cdot 32\end{array}$ \\
\hline $\begin{array}{l}\text { Persistently low } T L \\
\text { TL not persistently low }\end{array}$ & $\begin{array}{l}17 \\
30\end{array}$ & $\begin{array}{l}12 \\
20\end{array}$ & $\begin{array}{l}81 \cdot 4 \\
89 \cdot 2\end{array}$ & $\begin{array}{l}25 \cdot 33 \\
28 \cdot 68\end{array}$ & $\begin{array}{l}62 \cdot 2 \\
81 \cdot 2\end{array}$ & $\begin{array}{l}20 \cdot 19 \\
24 \cdot 8\end{array}$ \\
\hline
\end{tabular}

were expressed as \% $\mathrm{PN}$ and static recoil pressure as $\%$ predicted $^{15} ; \mathrm{r}$ for Dm was 0.41 , for Vc 0.16 .

\section{Discussion}

Transfer factor $(\mathrm{TL})$ measures the rate of passage of carbon monoxide across the alveoli into the capillary blood. It may be reduced when the ventilation of the lung is impaired, when the matching of ventilation/perfusion is very uneven, or when the amount of blood available in the capillaries for carbon monoxide uptake is reduced by anaemia or by obliteration of the vascular bed. Georges et $a l^{\mathbf{1 6}}$ suggest that where there is inhomogeneity of diffusing constants Vc may be better than Dm in estimation of pathological changes in the lungs. As the inflammatory and fibrotic change in rheumatoid disease have a patchy distribution this inhomogeneity may explain the finding in our study of reduction in Vc without significant fall in Dm.

In our patients the probability that the low Vc was related to rheumatoid disease was emphasised by the association of low Vc with the presence of nodules. There was however, no significant correlation with the number of joints involved or with Rose Waaler titre, whereas Kolarz ${ }^{17}$ found that abnormality of Kco was related to Rose Waaler titre. Treatment with penicillamine reduces the Rose Waaler titre, but exclusion of patients taking penicillamine did not produce any significant relationship between titre and Dm or Vc.

It was also noteworthy that treatment with corticosteroids seemed to prevent the change in Vc. If corticosteroid treatment had caused hypertension or left ventricular failure this would have produced a higher Vc, but there was no clinical evidence that this occurred. It seems more likely that corticosteroids suppress the inflammatory changes which have been described ${ }^{1-4}$ in pulmonary blood vessels of rheumatoid patients.

De Horatius and Williams ${ }^{18}$ showed deposition of antigammaglobulin in alveolar walls and arterioles after injection of rheumatoid factor. Postmortem studies $^{19}$ have demonstrated $\operatorname{IgM}$ in pulmonary arterioles and alveolar walls adjacent to cavitating rheumatoid nodules, and IgM in patients with "interstitial pneumonia." Such immunological reactions in pulmonary arterioles might be suppressed by treatment with corticosteroids. Gold and Jennings, ${ }^{20}$ studying 20 patients with systemic lupus erythematosus, a condition in which immune complex deposition is associated with vasculitis, found five patients in whom Vc was low, and there were associated physiological abnormalities indicative of pulmonary vascular obstruction.

From Hamer's ${ }^{21}$ study of sarcoidosis and from the study of systemic sclerosis ${ }^{16}$ it appeared that low Vc was associated with more advanced disease. In our patients Vc was significantly higher in patients with arthritis of longer duration, but 21 of the 27 patients whose arthritis had been present for more than 10 years were being treated with corticosteroids. Of eight patients not receiving corticosteroids whose Vc was less than $60 \%$ predicted, six had suffered from arthritis for less than 10 years.

Significant reduction of Vc was found in smokers rather than non-smokers and the difference between rheumatoid female smokers and non-smokers was 
the most significant in this study, although there was no difference between control female smokers and non-smokers. Some published results for Dm and Vc do not distinguish between smokers and non-smokers and there are more results for normal male than for normal female subjects. Frans et al ${ }^{10}$ studied healthy men and found that $\mathrm{Dm}$ and $\mathrm{Vc}$ were both lower in smokers. It was not possible to recruit a sufficient number of rheumatoid male patients who had never smoked, but normal male non-smokers have been studied in our laboratory. Pulmonary capillary volume was not significantly different from healthy male smokers. There is a suggestion from our results that the combination of rheumatoid disease and smoking reduces pulmonary capillary volume.

The patients in our study had been seen on a number of occasions and in $17 \mathrm{TL}$ had been persistently low. This was not explained by anaemia, which is common in rheumatoid disease. In these patients with persistently low $T_{L}$ Vc was significantly lower than in the other rheumatoid patients. In six of these 17 patients Kco was normal. It might be expected in these patients that the low transfer factor would be caused by low Dm associated with reduced alveolar volume. Membrane factor was low in three cases, in one of whom alveolar volume was low.

From equation 3 , since $\mathrm{Vc}$ is the capillary volume and $\theta$ the rate of uptake of oxygen by the red cell, it follows that the variable $\mathrm{Dm}$ must include the other factors influencing $\mathrm{TL}_{\mathrm{L}}$-that is, both ventilation of the alveoli and the structure and area of the alveolar wall and capillary membrane. Uneven and reduced alveolar ventilation could be caused by airways obstruction. Although this $\left(\mathrm{FEV}_{1} 2 \mathrm{SD}\right.$ below mean predicted normal) was fairly common in our patients and is associated with smoking, we found no evidence that it was associated with abnormal Dm or Vc. Georges et al ${ }^{16}$ found a highly significant correlation of effective compliance with Vc, but not with Dm. The sex and smoking habits of their patients were not given. It is probable that the majority of patients with systemic sclerosis were female, possibly non-smokers. The similarity of their results for DIPF and systemic sclerosis was very striking. In our patients correlation coefficients for Cdyn with Dm and Vc differed in direction for men and women, but were consistent for female smokers and non-smokers. The most significant relation between $\mathrm{Vc}$ and Cdyn was in female smokers, whereas in female non-smokers a relationship of lesser significance was found between Cdyn and Dm. For recoil pressure there was again better correlation with $\mathrm{Dm}$. Staub et $a \mathbf{l}^{22}$ found that increasingly negative oesophageal pressure in normal subjects was associated with increased TL and increased Vc. This would probably not be found if there were pathological changes in the arteries.

Macklem and Becklake ${ }^{23}$ found that in em- $\cong$ physema both recoil pressure and $\mathrm{T}_{\mathrm{L}}$ were reduced, $\infty$ in asthma recoil pressure and $T \mathrm{~L}$ were normal, but $\overrightarrow{0}$ in pulmonary fibrosis there was no correlation $\overrightarrow{-}$ between the two measurements. In rheumatoid $\tilde{\sigma}^{\circ}$ disease a greatly increased recoil pressure is attri- $\vec{\partial}$ butable to fibrotic changes in the lungs. On the other $x$ hand, patients with joint involvement of the thoracic of cage or muscles might produce smaller pressures and therefore lower $\mathrm{Dm}$ as a result of failure to achieve full ventilation of the alveoli. The mixture $\stackrel{G}{\rightarrow}$ of these different problems would make it impossible 은 to detect individual effects when studying the group as a whole.

Although in our patients there is a suggestion that in women there may be some relationship of Dm measurements to the mechanical properties $\underset{\mathbb{Q}}{\mathbb{Q}}$ of the lung, the notable abnormality is the reduction in Vc. This appears to be related to both smoking and rheumatoid disease and the change seems to be. suppressed by treatment with corticosteroids.

We thank Dr Alan Hill for permission to study his patients, the Arthritis and Rheumatism Council for financial support, Mrs S Davies and Mrs C Brown $\stackrel{\mathbb{Q}}{\varrho}$ for technical assistance, Dr R Greenwood for $\overrightarrow{\vec{B}}$ statistical advice, Mrs D Gulland for help with the $\frac{3}{3}$ bibliography, and Mrs $\mathrm{P}$ Boitoult and Mrs D Kingham for typing the manuscript.

\section{References}

1 Ellman P, Ball RE. Rheumatoid disease with $\underset{0}{\stackrel{x}{x}}$ joint and pulmonary manifestations. $\mathrm{Br} \mathrm{Med} J$ 1948; 2:816-20.

2 Price TML, Skelton MO. Rheumatoid arthritis with lung lesions. Thorax 1956; 11:234-40.

3 Edge JR, Rickards AG. Rheumatoid arthritis with lung lesions. Thorax 1957; 12:352-7.

4 Cruickshank B. Interstitial pneumonia and its consequences in rheumatoid disease. $\mathrm{Br} J$ Dis Chest 1959; 53:226-36.

5 Ognibene AJ. Systemic rheumatoid disease with N interstitial pulmonary fibrosis. Arch Intern Med స్ట 1960; 105:762-9.

6 Loddenkemper R, Bach GL, Carton RW. Diffusionsstörungen bei primärchronischer Poly- $\bullet$ arthritis and Lupus erythematodes disseminatus. Beitr Klin Tubek 1970; 141:230-41.

7 Morère $P$, Stain JP, Novet $G$ et al. Manifesta- 7 tions respiratoires de la polyarthrite chronique $\bar{O}$ rheumatöide. Rev Tuberc Pneumol 1972; 36: 77-84.

8 Frank ST, Weg JG, Harkleroad LE, Fitch RF. $\stackrel{\mathbb{2}}{\circ}$ Pulmonary dysfunction in rheumatoid disease. 
Chest 1973; 63:27-34.

9 Cotes JE. Lung function assessment and application in medicine. Fourth edition. Oxford: Blackwell Scientific Publications, 1979.

10 Frans A, Stanescu DC, Veriter C, Clerbaux J, Brasseur L. Smoking and pulmonary diffusing capacity. Scand J Respir Dis 1975; 56:165-83.

11 Roughton FJW, Forster RE. Relative importance of diffusion and chemical reaction rates in determining the rate of exchange of gases in the human lung. J Appl Physiol 1957; 11:290-302.

12 Hills EA, Davies S, Geary M. Frequency dependence of dynamic compliance in patients with rheumatoid arthritis. Thorax 1979; 34:755-61.

13 Cotes JE, Hall AM. The transfer factor for the lung: normal values in adults. In: Arcangeli $\mathbf{P}$ et al, eds. Symposium on Introduction to the Definition of Normal Values for Respiratory Function in Man. Milan: Panminerva Medica, 1970: $327-43$.

14 Frans A. Les valeurs normales due volume capillaire pulmonaire $(\mathrm{Vc})$ et de la capacité de diffusion de la membrane alveoli-capillaire (Dm). In: Arcangeli P et al, eds. Symposium on Introduction to the Definition of Normal Values for Respiratory Function in Man. Milan: Panminerva Medica, 1970: 352-63.

15 Knudson RJ, Clark DF, Kennedy TC, Knudson DE. Effect of aging alone on mechanical properties of the normal adult human lung. $J \mathrm{Appl}$ Physiol 1977; 43:1054-62.

16 Georges R, Saumon G, Lafosee JE, Turiaf J.
Membrane-diffusing capacity and pulmonary capillary blood volume. Progr Resp Res 1975; 8: 198-212.

17 Kolarz G, Schernthaner G, Scherak O, Kummer F. Correlation between lung function and clinical and serological features in rheumatoid arthritis. Scand J Rheumatol 1975; 8:066.

18 De Horatius RJ, Williams RC. Rheumatoid factor accentuation of pulmonary lesions associated with experimental diffuse proliferative lung disease. Arthritis Rheum 1972; 15:293-301.

19 De Horatius RJ, Abruzzo JL, Williams RC. Immunofluorescent and immunological studies of rheumatoid lung. Arch Intern Med 1972; 129: 441-6.

20 Gold WM, Jennings DM. Pulmonary function in patients with systemic lupus erythematosus. $\mathrm{Am}$ Rev Respir Dis 1966; 93:556-67.

21 Hamer NAJ. Changes in the components of the diffusing capacity in pulmonary sarcoidosis. Thorax $1963 ; 18: 275-87$.

22 Staub NC, Bruderman I, Queck C, Young R. Relation of pulmonary capillary blood volume (Vc) to lung volume and oesophageal pressure in normal man. Proceedings of the 22nd International Congress Union of Physiological Sciences. Amsterdam: Excerpta Medica, 1962: 304.

23 Macklem PT, Becklake MR. The relationship between the mechanical and diffusing properties of the lung in health and disease. Am Rev Respir Dis 1963; 87:47-56. 